\title{
Neuronal kinase SGK1.1 protects against brain damage after status epilepticus
}

Elva Martin-Batista, Laura E. Maglio, Natalia Armas-Capote, Guadalberto Hernandez, Diego Alvarez de la Rosa, Teresa Giraldez*

Departamento de Ciencias Médicas Básicas (Fisiología), Instituto de Tecnologías Biomédicas (ITB), Universidad de La Laguna, Tenerife, Spain

*To whom correspondence should be addressed:

Dr. Teresa Giraldez

Departamento de Ciencias Médicas Básicas - Área de Fisiología

Campus de Ciencias de la Salud s/n

Universidad de La Laguna

38071 La Laguna, Tenerife, Spain

Telephone: +34-922-319-356

E-mail: giraldez@ull.edu.es

Conflict of interest statement: The authors have declared that no conflict of interest exists.

Abbreviated tittle: Neuroprotective effect of SGK1.1

Number of pages: 21

Number of figures: 7

Number of words (Abstract): 169

Number of words (Introduction): 650

Number of words (Discussion): 1021

Acknowledgments:

We thank Dr Tomás Gonzalez and Dr Pedro Barroso for the help with FJC protocol. T.G. and D.A.R are members of the Red de Excelencia "Iniciativa Española en Canales lónicos". 
bioRxiv preprint doi: https://doi.org/10.1101/2020.04.03.024067; this version posted April 5, 2020. The copyright holder for this preprint (which was not certified by peer review) is the author/funder, who has granted bioRxiv a license to display the preprint in perpetuity. It is made available under aCC-BY 4.0 International license. 


\begin{abstract}
Epilepsy is a neurological condition associated to significant brain damage produced by status epilepticus (SE) including neurodegeneration, gliosis and ectopic neurogenesis. Reduction of these processes constitutes a useful strategy to improve recovery and ameliorate negative outcomes after an initial insult. SGK1.1, the neuronal isoform of the serum and glucocorticoids-regulated kinase 1 (SGK1), has been shown to increase M-current density in neurons, leading to reduced excitability and protection against seizures. We now show that SGK1.1 activation potently reduces levels of neuronal death and gliosis after SE induced by kainate, even in the context of high seizure activity. This neuroprotective effect is not exclusively a secondary effect of M-current activation but is also directly linked to decreased apoptosis levels through regulation of Bim and Bcl-X cellular levels. Our results demonstrate that this newly described antiapoptotic role of SGK1.1 activation acts synergistically with the regulation of cellular excitability, resulting in a significant reduction of SE-induced brain damage. The protective role of SGK1.1 occurs without altering basal neurogenesis in brain areas relevant to epileptogenesis.
\end{abstract}

\title{
SIGNIFICANCE STATEMENT
}

Approaches to control neuronal death and inflammation are of increasing interest in managing epilepsy, one of the most important idiopathic brain diseases. We have previously shown that activation of SGK1.1 reduces neuronal excitability by increasing M-current levels, significantly reducing seizure severity. We now describe a potent neuroprotective role of SGK1.1, which dramatically reduces neuronal death and gliosis after status epilepticus. This effect is partially dependent on M-current activation and includes an additional anti-apoptotic role of SGK1.1. Our data strongly support the relevance of this kinase as a potential target for epilepsy treatment. 
bioRxiv preprint doi: https://doi.org/10.1101/2020.04.03.024067; this version posted April 5, 2020. The copyright holder for this preprint (which

was not certified by peer review) is the author/funder, who has granted bioRxiv a license to display the preprint in perpetuity. It is made available under aCC-BY 4.0 International license.

\section{INTRODUCTION}

Epilepsy is a neurological disorder characterized by recurrent and unpredictable seizures, affecting more than 50 million people around the world. Temporal Lobe Epilepsy (TLE) is one of the most common types of epilepsy and the most refractory to treatment in humans. Two-thirds of TLE patients develop a sclerosis state caused by neuronal loss and gliosis (Mathern et al., 1997). Epileptogenesis has been associated to neurodegeneration (Dingledine et al., 2014), gliosis (Sofroniew, 2014), uncontrolled inflammation (Vezzani et al., 2011), and aberrant neurogenesis (Jessberger and Parent, 2015). This alteration in neurological homeostasis often results in a chronic epileptic condition (Pitkanen and Lukasiuk, 2009). Therefore, there is an increasing interest in the field of epilepsy research to develop new therapies targeting neuronal death and inflammation pathways.

Status epilepticus (SE) is defined as a period of continuous behavioral or electroencephalographic seizures lasting more than $30 \mathrm{~min}$. Chemically-induced-SE animal models reproduce most behavioral, electroencephalographic and neuropathological characteristics of TLE and have been widely used in basic epilepsy research to study this disorder (Levesque et al., 2016). SE-triggered negative outcomes in the brain include neuronal death, which has been associated to the appearance of new seizures (Mathern et al., 2002). Over-activation of glutamate receptors following SE constitutes a major cause of neuronal death. Elevation of $\mathrm{Na}^{+}$ and $\mathrm{Ca}^{2+}$ influx eventually leads to membrane disruption, cell lysis, release of free radicals and DNA degradation (Wang et al., 2005; Fujikawa, 2006). In addition, alterations in the expression of various biochemical markers for apoptosis have been related to seizure-induced neuronal loss, including members of the Bcl-2 gene family and caspases (Kim et al., 2014). Therefore, neuroprotection could be facilitated by two different but not necessarily unrelated general mechanisms. First, the activation of pathways limiting excitability. Secondly, the prevention of downstream events leading to apoptosis.

We have recently shown that increased activity of SGK1.1, the neuronal isoform of the serum and glucocorticoids-regulated kinase 1 (SGK1) potently reduces seizure duration and severity in a kainic acid (KA)induced SE paradigm with transgenic mice expressing a permanently active form of the kinase (Armas-Capote et al., 2019). Electrophysiological measurements in sympathetic neurons (Miranda et al., 2013) and hippocampal brain slices (Armas-Capote et al., 2019) showed that SGK1.1 up-regulates the neuronal M- current mediated by Kv7.2/7.3 ion channels. Altogether, our data suggested that SGK1.1 activation provides a mechanism securing the brain against epilepsy-related neuronal damage by controlling neuronal excitability.

In addition to the control of neuronal excitability, different studies have demonstrated that seizure-induced neuronal loss can be diminished by molecular and pharmacological approaches modulating apoptotic cell death (Henshall et al., 2002; Roy et al., 2002). Interestingly, SGK1 isoforms share high homology to the catalytic domain of the well described anti-apoptotic kinase AKT (Kobayashi et al., 1999). Both AKT and its upstream 
activator PI3K have been demonstrated to reduce apoptosis and promote neuronal survival in the central nervous system (Datta et al., 1997; Crowder and Freeman, 1998). The ubiquitous isoform SGK1 shows cellsurvival and anti-apoptotic effects (Brunet et al., 2001; Ferrelli et al., 2015) and has been linked to neuroprotection in stroke (McCaig, 2019; Wang, 2019). Taking all this into account, we hypothesized that in addition to the observed reduction in neuronal excitability, SGK1.1 activation could directly reduce apoptosis levels post-SE. In this study we have extensively quantified neuronal death levels following KA-induced SE in different brain areas of WT and transgenic mice with constitutively active SGK1.1 expression. Our data show that increased SGK1.1 activity in the transgenic mouse model dramatically reduces neuronal death associated to KA-induced seizures. This effect is associated to significantly diminished inflammatory processes and the absence of ectopic neurogenesis. Finally, activation of the kinase is associated to altered levels of apoptotic biomarkers consistent with lower apoptosis levels. In summary, we demonstrate the existence of a dual mechanism underlying SGK1.1-mediated protection against neuronal death involving not only the modulation of neuronal excitability, but also the additional modulation of cellular pathways leading to apoptosis. 


\section{MATERIAL AND METHODS}

\section{Antibodies and chemicals}

Antibodies against Bcl-2 interacting mediator of cell death (Bim;sc-374358) and B-cell lymphoma-extra large (Bcl-xL;Sc-8392) were obtained from Santa Cruz Biotechnology (Santa Cruz, CA); anti-parvalbumin (PV;P3088) and anti-glial fibrillary acidic protein (GFAP;G3893) antibodies were obtained from Sigma-Aldrich; bromodeoxyuridine (BrdU, NBP2-14890) was obtained from Novus; rabbit Anti-Goat IgG conjugated to Alexa Fluor ${ }^{\circledR} 488$ (ab150141), anti-Doublecortin (DCX;ab153668) and anti-ionized calcium-binding adapter molecule 1 (Iba-1;ab5076) were obtained from Abcam; goat anti-mouse IgG conjugated to Alexa Fluor® 594 (A-11005), goat anti-chicken IgY conjutated to Alexa Fluor ${ }^{\circledR} 94$ (A-11042), goat anti-rabbit IgG conjugated to Alexa Fluor $\AA$ 488 (A-11008) and anti-calcium/calmodulin-dependent protein kinase II (CaMKII;MA1-048) were obtained from Thermo Fisher Scientific. A rabbit polyclonal antibody against SGK1.1 was generated against a glutathione Stransferase (GST) fusion protein containing amino acids 41-80 from the SGK1.1-specific exon 2, expressed in $E$. coli and purified by affinity chromatography. KA (K0250) and M-current blocker XE991 (X2254) were obtained from Sigma Aldrich. SGK1 inhibitor EMD638683 was from MedChem Express (HY-15193A).

\section{Animals and seizure induction}

Animal handling and experimental procedures were approved by Universidad de La Laguna Ethics Committee and conform to Spanish and European guidelines for protection of experimental animals (RD53/2013; 2010/63/EU). This work is based on the use of a transgenic mouse model previously generated in our laboratory, B6.Tg.sgk1 (Miranda et al., 2013; Armas-Capote et al., 2019). Briefly, the transgenic line was created with a bacterial artificial chromosome containing the whole Sgk1 gene and a point mutation (S422D in the ubiquitous isoform SGK1; S515D in the neuronal isoform SGK1.1) that renders the kinase constitutively active. The BAC expresses Sgk1 splice isoforms under their own promoters and results in expression of the neuronal isoform SGK1.1 in the brain (Arteaga et al. 2008). Founder animals were crossed with wild type C57BL/6J for at least nine generations. All experiments described here were performed in homozygous mice obtained by crossing heterozygous animals. FVB.Tg.sgk1 mice were generated by transferring the transgene to the inbred strain FVB/N, backcrossing for 9 generations (Armas-Capote et al., 2019). Wild type mice (B6.WT or FVB.WT) in the same genetic background (C57BL/6J or FVB/N) were used as controls. Seizures were induced in 16-22 weeksold mice with intraperitoneal (ip) injection of $20 \mathrm{mg} / \mathrm{kg} \mathrm{KA}$ as previously described (Armas-Capote et al., 2019). Seizure behavior was evaluated for $2 \mathrm{~h}$ using a modified Racine scale: 0 , no response, 1, immobility, 2, rigid posture and tail extension, 3, head bobbing and repetitive movements, 4, rearing, 5 rearing and falling continuously, 6, tonic-clonic generalized seizures and 7, death. Only mice reaching score 6 were included in the histological studies. Where indicated, XE991 (10 mg/kg) or EMD638683 (1.6 mg/kg) were administered ip $1 \mathrm{~h}$ or 
bioRxiv preprint doi: https://doi.org/10.1101/2020.04.03.024067; this version posted April 5, 2020. The copyright holder for this preprint (which

was not certified by peer review) is the author/funder, who has granted bioRxiv a license to display the preprint in perpetuity. It is made available under aCC-BY 4.0 International license.

1 day prior to KA injection respectively, as described elsewhere (Armas-Capote et al., 2019). Mice injected with saline were used as controls.

\section{Western Blot Analysis}

Hippocampi were collected $24 \mathrm{~h}$ after KA treatment and protein extracts were obtained by processing samples with lysis buffer (Tris-Base 0.5 M, pH 7.4; SDS $10 \%$ ) containing phosphatase and proteinase inhibitors (Roche). Lysates were clarified by centrifugation at $14000 \times \mathrm{g}$ for $10 \mathrm{~min}$ and protein concentration was measured using the bicinchoninic acid assay. Proteins were separated by SDS denaturing gel electrophoresis (SDS-PAGE), transferred to a polyvinylidene fluoride membrane and analyzed by western blot (WB). Chemiluminescence signals were analyzed using Image Lab® software 6.0 (Bio-Rad).

\section{Histological sample preparation}

Three days after KA treatment, mice were deeply anesthetized (sodium pentobarbital, $40 \mathrm{mg} / \mathrm{kg}$, ip) and perfused transcardially with saline ( $\mathrm{NaCl}$ 0,9\%) and paraformaldehyde (PFA) 4\% in $0.1 \mathrm{M}$ phosphate-buffered saline pH 7.4 (PBS). Dissected brains were post-fixed in PFA for $24 \mathrm{~h}\left(4^{\circ} \mathrm{C}\right)$ before being transferred to sucrose $30 \%$ for cryoprotection overnight $\left(-80^{\circ} \mathrm{C}\right)$. Thick coronal sections $(30 \mu \mathrm{m})$ were obtained using a freezing microtome. Saline-injected animals were used as controls.

\section{Neurodegeneration quantification by Fluoro-Jade C staining}

Coronal slices were stained with Fluoro-Jade C (FJC), an anionic fluorochrome capable of selectively staining degenerating neurons in brain slices (Schmued et al., 1997). Neuronal degeneration was evaluated $72 \mathrm{~h}$ after KA injection in WT and Tg.sgk1 mice reaching Racine stage 6, following a previously described protocol (Afonso-Oramas et al., 2010). Sections were examined using confocal microscopy (Leica TCS SP8). Image analysis was performed using ImageJ software (Schindelin et al., 2012). Five different sections were selected for each animal (from -1.355 to -3.08 in reference to bregma, Allen Institute for Brain Science, 2014) providing a total of five individual values per region for each animal. Measurements from all sections were averaged to obtain one final measurement per region.

\section{Gliosis quantification by immunohistochemistry}

The presence of reactive gliosis $72 \mathrm{~h}$ post-KA injection was assessed by measuring the expression of GFAP in astrocytes and Iba-1 in microglia. One set of coronal sections (between -1.755 and $-2.155 \mathrm{~mm}$ from bregma) was selected for evaluation of potential GFAP and Iba-1 variations after KA. Briefly, sections were washed three times with PBS, blocked with 4\% goat serum for $1 \mathrm{~h}$ and incubated overnight with anti-GFAP at 1:400 or anti-Iba1 at 1:500 diluted in 2\% goat serum. Sections were then washed 3-4 times in PBS before incubation with secondary antibodies conjugated to Alexa Fluor® 594 at 1:200 or Alexa Fluor® 488 at 1:1000 for 2 h. Finally, 
bioRxiv preprint doi: https://doi.org/10.1101/2020.04.03.024067; this version posted April 5, 2020. The copyright holder for this preprint (which

was not certified by peer review) is the author/funder, who has granted bioRxiv a license to display the preprint in perpetuity. It is made available under aCC-BY 4.0 International license.

sections were washed and mounted with Mowiol and 4',6-diamidino-2-phenylindole (DAPI) for examination under confocal microscopy. Measurements from the two hemispheres were obtained and averaged as GFAP area/DAPI area using ImageJ software.

\section{Neurogenesis quantification by BrdU incorporation and immunohistochemistry}

We tested the effect of SGK1.1 activation on ectopic neurogenesis processes using BrdU incorporation and DCX staining on brain slices. Adult B6.WT and B6.Tg.sgk1 BrdU-injected mice (50 mg/kg, twice) were perfused with PFA 4\% $24 \mathrm{~h}$ after injection. Brains were removed and post-fixed in PFA 4\% and $50 \mu \mathrm{m}$ coronal brain slices were obtained with a freezing microtome. After blocking with $1 \%$ serum in PBS and $1 \%$ Triton X-100, and DNA denaturation with hydrochloric and boric acid $\left(2 \mathrm{~N}\right.$ at $37^{\circ} \mathrm{C} 30 \mathrm{~min}$ and $0,1 \mathrm{M}$ at $\mathrm{RT} 10 \mathrm{~min}$ respectively), proliferating cells were detected with rabbit anti-BrdU antibody at $1: 500\left(72 \mathrm{~h}\right.$ at $\left.4^{\circ} \mathrm{C}\right)$ followed by anti-rabbit Alexa Fluor ${ }^{\circledR} 488$ antibody at 1:1000. Proliferating cells $\left(\mathrm{BrdU}^{+}\right)$in the hilus (ectopic neurogenesis) and subgranular layer (newborn cells) of the dentate gyrus (DG) were quantified and compared in transgenic and WT mice. Additionally, the amount of adult neuronal proliferation was evaluated by the presence of DCX-positive $\left(\mathrm{DCX}^{+}\right)$neuroblasts in DG using a chicken anti-DCX antibody at 1:500 and anti-chicken Alexa Fluor® 594 antibody at 1:1000 (Kuhn, 1996; Pérez-Domper et al., 2017).

\section{Cell culture and transfection}

Human embryonic kidney cells HEK293T were obtained from the American Type Culture Collection (Manassas, VA) and maintained in DMEM supplemented with 10\% FBS. Cells were transfected 24-48 h before experiments using Jetprime (Polyplus Transfection, Illkirch) following the manufacturer's instructions. Plasmid constructs for WT, mutant SGK1.1 and AKT expression have been previously described (Coric et al., 2004; Arteaga et al., 2008; Wesch et al., 2010); pECFP-N1 was obtained from Clontech.

Terminal deoxynucleotidyl transferase dUTP nick end labeling (TUNEL) Assay

In order to evaluate the potential anti-apoptotic role of SGK1.1, we performed TUNEL assays in HEK293T cells. Briefly, cells were transiently transfected with SGK1.1 dominant negative mutant (SGK1.1 ${ }^{\mathrm{K} 220 \mathrm{~A}}$ ), a mutant rendering the kinase constitutively active (SGK1.15515D) or a mutant targeting it to the nucleus (SGK1.1 ${ }^{\mathrm{FF} 19,20 \mathrm{AA}}$ ). AKT was used as a positive control for anti-apoptotic effects. An empty vector (pECFP-N1) was used to control for transfection toxicity. Cells were treated with $1 \mathrm{mM}$ hydrogen peroxide $\left(\mathrm{H}_{2} \mathrm{O}_{2}\right)$ for $4 \mathrm{~h}$ to induce apoptosis. The TUNEL protocol was performed using a commercial kit (ApopTag® fluorescein in situ apoptosis detection kit, Millipore). Apoptotic cells were detected as localized bright green cells in a blue background (DAPI) by confocal microscopy.

\section{Experimental design and statistical analysis}


bioRxiv preprint doi: https://doi.org/10.1101/2020.04.03.024067; this version posted April 5, 2020. The copyright holder for this preprint (which was not certified by peer review) is the author/funder, who has granted bioRxiv a license to display the preprint in perpetuity. It is made available under aCC-BY 4.0 International license.

Statistical analysis was performed using Prism 8 (GraphPad). Prior to any statistical analysis, we assessed normality distribution of our data using D'Agostino-Pearson or Shapiro-Wilk normality test. Once normality was established, we compared data means using t-test or one-way ANOVA test for parametric distributions and Mann-Whitney for non-parametric distributions. Specific statistical tests and number of experiments/samples and/or animals (indicated by $\mathrm{n}$ and $\mathrm{N}$, respectively) are indicated in each figure legend. 


\section{RESULTS}

\section{SGK1.1 protects mice from kainate-induced neuronal death}

We have previously shown that transgenic mice expressing a constitutively active form of the kinase (B6.Tg.sgk1) show significantly reduced seizure severity in the KA-induced SE animal paradigm (Armas-Capote et al., 2019). This is reflected in fewer mice reaching more severe Racine stages and associated mortality (Figure 1A). In this study we evaluated the impact of increased SGK1.1 activity in neurodegeneration and gliosis on mice surviving KA treatment. For this purpose, we selected mice reaching Racine stage 6 (generalized tonicclonic seizures; Figure 1A, orange box). We reasoned that the comparison of transgenic mice with their WT counterparts that are reaching comparable seizure severity levels would allow us to unveil the potential contribution of additional neuroprotective mechanisms activated by SGK1.1 independent of seizure protection (Armas-Capote et al., 2019). Neurodegeneration was quantified by FJC staining of brain slices from B6.WT and B6.Tg.sgk1 mice reaching tonic-clonic seizures (Racine 6). As shown in Figure 1B (left panels), significant levels of neuronal damage were observed in B6.WT mice, reflected as a significant number of FJC-stained cells (Figure 1C). This result was comparable to previous reports using similar experimental conditions (Hopkins et al., 2000; Yan et al., 2018). In contrast, activation of SGK1.1 in B6.Tg.sgk1 neurons conferred a remarkable level of protection against neuronal death in all brain areas studied, including hippocampus, somatosensorial auditive and piriform-entorhinal cortex (Figure 1B, right panels, and Figure 1C). This observation is especially striking taking into account that all B6.Tg.sgk1 mice reached tonic-clonic convulsions, suggesting the possibility that protective mechanisms are activated by SGK1.1 even in conditions of neuronal hyperexcitability. The neuroprotective effect associated to SGK1.1 activation was not specific of the C57BL/6J genetic background. Similar results were obtained with transgenic mice generated on the FVB background, which has been proposed to display increased seizure susceptibility to KA (Schauwecker and Steward, 1997; McKhann et al., 2003; Kasugai et al., 2007) (Figure 1D-F).

To assess that the observed effects were a direct consequence of kinase activation, mice were acutely pretreated with the SGK1.1 inhibitor EMD638683. As shown in Figure 2A and consistent with previous reports (Armas-Capote et al., 2019), inhibition of the kinase reverted the protective effect and abolished all differences in seizure behavior between genotypes (Figure 2A). Importantly, identical levels of neuronal death were observed in B6.WT and B6.Tg.sgk1 mice (Figure 2B-C) in all brain areas. These results demonstrate that kinase activity underlies the mechanism reducing neuronal death associated to KA-induced seizures.

We have previously demonstrated that the regulation of the M-current by SGK1.1 underlies the protection mechanism against seizures progression and severity, since pre-treatment of mice with XE991 fully counteracts the effect of the kinase in transgenic mice (Armas-Capote et al. 2019 and Fig.2D). Quantification of neuronal 
bioRxiv preprint doi: https://doi.org/10.1101/2020.04.03.024067; this version posted April 5, 2020. The copyright holder for this preprint (which

was not certified by peer review) is the author/funder, who has granted bioRxiv a license to display the preprint in perpetuity. It is made available under aCC-BY 4.0 International license.

death in this experimental condition allowed us to assess the existence of neuroprotective mechanisms that are independent of the alterations in neuronal excitability associated to SGK1.1 activation. Augmented cell excitability in XE-991 transgenic neurons led to less pronounced differences in neuronal loss between WT and Tg.sgk1 genotypes (Figure 2D-F). However, we still observed a statistically significant reduction in neuronal death levels at the piriform cortex from Tg.sgk1 mice, and a clear tendency towards decreased death levels in all the other brain areas studied (Figure 2F). Importantly, piriform, perirhinal and entorhinal cortex have been described as key seizure-trigger zones (Vismer et al., 2015). This result strongly supports the hypothesis that SGK1.1 neuroprotective role may include additional mechanisms that are independent of its effects on neuronal excitability.

\section{Activation of sgk1.1 reduces levels of reactive gliosis after status epilepticus}

Glial cells have an essential role in maintaining brain homeostasis. Growing evidence supports the hypothesis that inflammation is a consequence as well as a cause of epilepsy (Vezzani, 2007; Choi et al., 2009; Riazi et al., 2010; Vezzani et al., 2011). We quantified the occurrence of gliosis on brain slices from WT and Tg.sgk1 after SE (Racine stage 6). First, GFAP was used as a marker of astrocyte activation to assess astrogliosis levels. As shown in Figure 3A-B, SGK1.1 activation in Tg.sgk1 mice significantly reduced astrogliosis secondary to KA injection in all brain areas, including hippocampus and cortex. Similar to previous observations, this effect was retained in FVB mice, indicating that it was not associated to specific genetic backgrounds (Figure 3C-D). Additionally, we measured microgliosis levels using Iba-1 as a marker. Quantitative analysis revealed significantly lower levels of reactive microglia in B6.Tg.sgk1 mice compared to B6.WT (Figure 4A-B). Similar results were obtained after evaluating the levels of reactive microglia in FVB.WT and FVB.Tg.sgk1 mice, indicating that the effects of SGK1.1 activation on microgliosis are also independent of the genetic background (Figure 4C-D). Our results unveil a new role of SGK1.1 in diminishing reactivity of glial cells, potentially leading to reduced levels of inflammation and structural changes in the damaged brain.

\section{SGK1.1 is mainly expressed in pyramidal neurons}

The distribution of the SGK1.1 protein in the brain remained elusive, due to the lack of isoform-specific antibodies. To overcome this limitation, we developed a novel rabbit polyclonal antibody raised against an isoform-specific epitope purified from $E$. coli. The new serum specifically recognized SGK1.1 without crossreacting with the endogenously expressed ubiquitous isoform SGK1 (Figure 5A). Immunohistochemical localization of SGK1.1 in mouse hippocampus and cortex revealed specific expression in pyramidal neurons as demonstrated by the co-localization with CaMKII (Figure 5B-C). These results are consistent with our previous report that SGK1.1 mRNA is preferentially expressed in pyramidal neurons of the cortex and hippocampus (Wesch et al., 2010). Interestingly, in hippocampus we observed homogeneous expression in all regions that 
bioRxiv preprint doi: https://doi.org/10.1101/2020.04.03.024067; this version posted April 5, 2020. The copyright holder for this preprint (which

was not certified by peer review) is the author/funder, who has granted bioRxiv a license to display the preprint in perpetuity. It is made available under aCC-BY 4.0 International license.

constitute the glutamatergic circuit involved in excitatory synaptic transmission (see upper panels in Figure 5B CA1- and 5E -CA3-). Double immunohistochemistry also revealed that SGK1.1 is not expressed in parvalbuminpositive interneurons (Figure 5D) or GFAP-expressing astrocytes (Figure 5E-F), further reinforcing the idea that expression of this kinase is restricted to pyramidal neurons, as previously suggested by in situ hybridization (Wesch et al., 2010). Within pyramidal neurons, expression is detectable in the soma and neuronal processes (Figure 5B and Figure 5E, left panels), with no positive signal in the nuclei. This localization pattern strongly suggests that SGK1.1 site of action is primarily neuronal and that the decrease in reactive gliosis is secondary to the reduction of neuronal death.

\section{SGK1.1 decreases apoptosis after KA-induced SE}

Given the fact that SGK1.1 catalytic domain shares high homology with the catalytic domain of the well described anti-apoptotic kinase AKT (Kobayashi et al., 1999), and that the ubiquitous isoform SGK1 has antiapoptotic activity (Ferrelli et al., 2015), we evaluated the ability of SGK1.1 to reduce the levels of apoptosis in an in vitro model using the TUNEL assay (Crowley et al., 2016). As previously described, apoptosis levels were significantly reduced in $\mathrm{H}_{2} \mathrm{O}_{2}$-treated HEK293T cells expressing AKT (Park et al., 2016) (Figure 6A, middle row and Figure 6B, grey bar). Heterologous expression of the constitutively active form of SGK1.1 lead to similar results, supporting the potential role of this kinase as an antiapoptotic factor (Figure 6A-lower row and Figure 6B, green bar). In contrast, this effect was abolished in cells expressing a kinase-dead mutant of SGK1.1 (K220A) (Figure 6B, orange bar) (Arteaga et al., 2008; Wesch et al., 2010). Finally, heterologous expression of a mutant with constitutive nuclear localization (FF19.20AA) showed higher sensitivity to $\mathrm{H}_{2} \mathrm{O}_{2}$-induced apoptosis (Figure 6B, purple bar), indicating that correct subcellular targeting is essential for SGK1.1 anti-apoptotic effects.

Altogether, these results support the idea that SGK1.1 could act as an anti-apoptotic factor in vivo, decreasing SE-induced apoptosis in the mouse hippocampus. We tested this hypothesis by quantifying the expression of different markers of apoptotic pathways. First, we evaluated how activation of SGK1.1 in the transgenic mice affected the levels of Bim, a known pro-apoptotic marker of the intrinsic apoptosis pathway (O'Connor et al., 1998; Engel and Henshall, 2009; Kim et al., 2014). Western blot analysis performed $24 \mathrm{~h}$ after KA-induced SE showed significantly decreased levels of Bim in Tg.sgk1 mice vs. WT (Figure 6C and Figure 6E). Bands corresponding to the molecular mass of the three existing splice isoforms of Bim $\left(\operatorname{Bim}_{\mathrm{S}}, \mathrm{Bim}_{\mathrm{L}}\right.$ and Bim $\left.\mathrm{EL}\right)$ (Putcha et al., 2001) were detected (Figure 6C). Additionally, we analyzed the expression of Bcl- $\mathrm{x}_{\mathrm{L}}$, a member of the antiapoptotic Bcl-2 protein family. This factor has been proposed to reduce apoptosis by preventing mitochondrial permeability transition associated to release of pro-apoptotic factors, therefore contributing to maintain cell viability in the central nervous system (Boise et al., 1993; Krajewska et al., 2002; Jonas et al., 2014). Consistent with the hypothesis that SGK1.1 activation can exert anti-apoptotic effects, western blot experiments show 
significantly increased Bcl-X $\mathrm{L}$ protein abundance in the hippocampus of Tg.sgk1 mice vs. WT following KAinduced seizures (Figure 6D and Figure 6E).

Taken together, our results show that activation of SGK1.1 is a potent mechanism of neuroprotection after SE, with a striking reduction in neuronal death accompanied by a very prominent reduction in reactive gliosis. Mechanistically, this effect underlies a combination of two main factors. In addition to previously demonstrated decreased neuronal excitability due to increased M-current density, we now demonstrate that SGK1.1 activation triggers anti-apoptotic signaling pathways involving altered levels of Bim and Bcl-XL proteins.

Transgenic mice do not show hippocampal ectopic neurogenesis

The existence of aberrant hippocampal neurogenesis in the subgranular region of the DG has been related to epilepsy (Parent et al., 2006; Chugh et al., 2015). Previous studies have suggested that SGK1 might be associated with neurogenesis in hippocampus triggered by glucocorticoid hormones (Anacker et al., 2013). Therefore, if SGK1.1 is to be evaluated as a valid pharmacological target in the treatment of epilepsy, it is important to determine whether constitutive activation of SGK1.1 in our animal model has side effects on ectopic neurogenesis. In this study, we quantified neurogenesis by BrdU incorporation and DCX staining in granular cells of the DG and hilus (Figure 7). Our results showed no significant differences in normal or ectopic neurogenesis in transgenic mice vs. WT (Figure 7). This finding supports the conclusion that activation of SGK1.1 does not produce aberrant neurogenesis. 


\section{DISCUSSION}

Our work demonstrates that SGK1.1, which has been previously shown as a modulator of Kv7 channels that potently reduces KA-induced seizure severity (Miranda et al., 2013; Armas-Capote et al., 2019), exerts a dual protecting role by additionally modulating and reducing seizure-induced cell damage in the brain. Importantly, this effect is robust and independent of the genetic background. It is maintained in FVB/NJ mice, a strain associated to higher levels of neurodegeneration than C57BL/6J (Royle et al., 1999; Kasugai et al., 2007). Neuroprotection is due to SGK1.1 activation, since acute kinase inhibition with the specific inhibitor EMD638683 lead to equal levels of neuronal death in both genotypes. This result also rules out that the observed effects are a consequence of long-term changes induced by the expression of the transgene. Inhibition of the M-current by pre-treatment with the Kv7 blocker XE991 abolished differences in behavioral seizures between genotypes (Fig.2), as well as the decrease in CA1 excitability associated to activation of the kinase (Armas-Capote et al., 2019). Strikingly, transgenic mice still showed significantly reduced neuronal death levels in relevant brain areas after the KA challenge, suggesting that activation of SGK1.1 modulates pathways preventing neuronal death independently of its role in membrane Kv7 modulation.

The mechanism underlying this observed SGK1.1-mediated protection against neuronal death relays at least partially on the role of this kinase as an anti-apoptotic factor in the brain. First, our data show that SGK1.1 activation reduces $\mathrm{H}_{2} \mathrm{O}_{2}$-induced apoptosis to similar extents than AKT. This finding is not surprising, given the shared homology of SGK1.1 and AKT catalytic domains. Further, the existence of such homology makes it tempting to hypothesize that both kinases might share downstream substrates including the anti-apoptotic transcriptional factor Bim, which has been related to SE-brain damage with FOXO3a and caspase-3 (Kim et al., 2014). Consistent with this notion, we now show that activation of SGK1.1 in Tg.sgk1 mice reduces Bim protein levels in hippocampus, whereas Bcl-X is upregulated. Importantly, both members of the Bcl-2 family have been described as key regulators of the mitochondrial (intrinsic) apoptotic pathway (Youle and Strasser, 2008) and related to seizure-induced brain damage (Murphy et al., 2010; Kim et al., 2014). Increased levels of Bim have been reported in mice and rats after KA-induced SE, while Bim-deficient mice show reduced levels of neurodegeneration (Motoyama et al., 1995). Bim localizes to intracellular membranes, where it has been proposed to induce apoptotic cell death via caspase activation (O'Connor et al., 1998). This proapoptotic effect is blocked by interaction with $\mathrm{Bcl}-\mathrm{xL}$, an anti-apoptotic factor found in mature neurons in the adult brain (Motoyama et al., 1995; Roth et al., 2000). Accordingly, Bcl-XL-deficient mice show massive neuronal cell death (Motoyama et al., 1995). Our results showing modulation of both factors in transgenic mice are consistent with the observed significantly lower levels of neurodegeneration that are associated to activation of SGK1.1. 
bioRxiv preprint doi: https://doi.org/10.1101/2020.04.03.024067; this version posted April 5, 2020. The copyright holder for this preprint (which

was not certified by peer review) is the author/funder, who has granted bioRxiv a license to display the preprint in perpetuity. It is made available under aCC-BY 4.0 International license.

A potential ramification of the anti-apoptotic role of SGK1.1 could be the existence of deleterious pro-proliferative effects (Brunet et al., 2001). In the framework of the observed neuroprotective effects of SGK1.1 activation, and taken into account previous reports of SGK1 effects (Anacker et al., 2013), we were especially concerned about the potential induction of aberrant hippocampal neurogenesis in the DG (Parent et al., 2006; Löscher, 2012; Chugh et al., 2015). It has been proposed that this ectopic neurogenesis after seizure-induced damage could result in the alteration of neuronal electrophysiological properties, contributing to the generation of hyperexcitable circuits. This process has been involved in the maintenance of epileptic activity (Ribak et al., 2000; Parent et al., 2006). However, our data did not reveal significant differences in the levels of ectopic neurogenesis in the DG of Tg.sgk1 vs. WT mice, ruling out this possibility (Parent et al., 2006; Anacker et al., 2013). It will be interesting to address in the future whether there is any difference in ectopic neurogenesis between Tg.sgk1 and WT mice after KA treatment, both in acute conditions as well as in animals undergoing recurrent spontaneous seizures (acquired epilepsy). Neurodegeneration has been described as one of the most common alterations found in epilepsy patients contributing to progression towards a sclerotic and hardened brain (Mathern et al., 1997; Mathern et al., 2002; Goldberg and Coulter, 2013). Although there is a growing body of evidence supporting that neuroprotection does not prevent development of acquired epilepsy (André et al., 2001; Löscher, 2002; Pitkänen, 2002; Brandt et al., 2003), it has been proven that alleviation of neurodegeneration diminishes adverse effects of SE and might improve recovery (Bolanos et al., 1998; Pitkänen and Kubova, 2004; Brandt et al., 2006). Proinflammatory mediators, reactive astrocytes and microglia have been found in the resected hippocampi of TLE patients and might contribute to the generation of new seizures (Crespel et al., 2002; Aronica et al., 2007; Ravizza et al., 2008; Van Gassen et al., 2008). However, it is not clear whether inflammation is a consequence or a cause of epilepsy (Vezzani, 2007; Choi et al., 2009; Riazi et al., 2010; Vezzani et al., 2011). In the present work, we demonstrate that while SGK1.1 is not expressed in astrocytes, its neuronal activation prevents reactive gliosis in a transgenic mouse model, limiting the extent of overall brain damage. Furthermore, our results support the idea that, at least in the animal model used in this study, gliosis occurs as a consequence of neuronal death.

Although epilepsy research has allowed the development and improvement of different available treatments, there is still a great need for approaches able to control seizures in approximately $30 \%$ of the patients showing resistance to antiepileptic drugs (Löscher and Schmidt, 2011). New strategies suitable to diminish and reduce brain damage after SE might help to prevent the progression of the disease as well as the deterioration of neuronal tissue, which is usually accompanied by a long list of comorbidities and psychiatric dysfunctions (Kobau et al., 2006; Tellez-Zenteno et al., 2007; Elliott et al., 2009; Kanner et al., 2010). The present work, together with our previously published results (Miranda et al., 2013; Armas-Capote et al., 2019) strongly 
bioRxiv preprint doi: https://doi.org/10.1101/2020.04.03.024067; this version posted April 5, 2020. The copyright holder for this preprint (which was not certified by peer review) is the author/funder, who has granted bioRxiv a license to display the preprint in perpetuity. It is made available under aCC-BY 4.0 International license.

supports a dual role of SGK1.1 as an anti-convulsant and neuroprotective factor, which could open new therapeutic avenues in epilepsy. 


\section{REFERENCES}

Afonso-Oramas D, Cruz-Muros I, Barroso-Chinea P, Alvarez de la Rosa D, Castro-Hernandez J, Salas-Hernandez J, Giraldez T, Gonzalez-Hernandez T (2010) The dopamine transporter is differentially regulated after dopaminergic lesion. Neurobiol Dis 40:518-530.

Anacker C, Cattaneo A, Musaelyan K, Zunszain PA, Horowitz M, Molteni R, Luoni A, Calabrese F, Tansey K, Gennarelli M, Thuret S, Price J, Uher R, Riva MA, Pariante CM (2013) Role for the kinase SGK1 in stress, depression, and glucocorticoid effects on hippocampal neurogenesis. Proceedings of the National Academy of Sciences of the United States of America 110:8708-8713.

André V, Ferrandon A, Marescaux C, Nehlig A (2001) Vigabatrin protects against hippocampal damage but is not antiepileptogenic in the lithium-pilocarpine model of temporal lobe epilepsy. Epilepsy Research 47:99117.

Armas-Capote N, Maglio LE, Perez-Atencio L, Martin-Batista E, Reboreda A, Barios JA, Hernandez G, Alvarez de la Rosa D, Lamas JA, Barrio LC, Giraldez T (2019) SGK1.1 Reduces Kainic Acid-Induced Seizure Severity and Leads to Rapid Termination of Seizures. Cereb Cortex.

Aronica E, Boer K, van Vliet EA, Redeker S, Baayen JC, Spliet WGM, van Rijen PC, Troost D, Lopes da Silva FH, Wadman WJ, Gorter JA (2007) Complement activation in experimental and human temporal lobe epilepsy. Neurobiology of Disease 26:497-511.

Arteaga MF, Coric T, Straub C, Canessa CM (2008) A brain-specific SGK1 splice isoform regulates expression of ASIC1 in neurons. Proceedings of the National Academy of Sciences of the United States of America 105:4459-4464.

Boise LH, González-García M, Postema CE, Ding L, Lindsten T, Turka LA, Mao X, Nuñez G, Thompson CB (1993) Bcl-X, a Bcl-2-Related Gene That Functions As a Dominant Regulator of Apoptotic Cell Death. Cell 74:597608.

Bolanos AR, Sarkisian M, Yang Y, Hori A, Helmers SL, Mikati M, Tandon P, Stafstrom CE, Holmes GL (1998) Comparison of valproate and phenobarbital treatment after status epilepticus in rats. Neurology 51:41-48.

Brandt C, Potschka H, Löscher W, Ebert U (2003) N-methyl-D-aspartate receptor blockade after status epilepticus protects against limbic brain damage but not against epilepsy in the kainate model of temporal lobe epilepsy. Neuroscience 118:727-740.

Brandt C, Gastens AM, Sun Mz, Hausknecht M, Löscher W (2006) Treatment with valproate after status epilepticus: Effect on neuronal damage, epileptogenesis, and behavioral alterations in rats. Neuropharmacology 51:789-804.

Brunet A, Park J, Tran H, Hu LS, Hemmings BA, Greenberg ME (2001) Protein Kinase SGK Mediates Survival Signals by Phosphorylating the Forkhead Transcription Factor FKHRL1 (FOXO3a). In: Molecular and Cellular Biology, pp 952-965.

Choi J, Nordli DR, Alden TD, DiPatri A, Laux L, Kelley K, Rosenow J, Schuele SU, Rajaram V, Koh S (2009) Cellular injury and neuroinflammation in children with chronic intractable epilepsy. Journal of neuroinflammation 6:1-14.

Chugh D, Ali I, Bakochi A, Bahonjic E, Etholm L, Ekdahl CT (2015) Alterations in Brain Inflammation, Synaptic Proteins, and Adult Hippocampal Neurogenesis during Epileptogenesis in Mice Lacking Synapsin2. PloS one 10:e0132366.

Coric T, Hernandez N, Alvarez De La Rosa D, Shao D, Wang T, Canessa CM (2004) Expression of ENaC and serum- and glucocorticoid-induced kinase 1 in the rat intestinal epithelium. American Journal of Physiology - Gastrointestinal and Liver Physiology 286. 
Crespel A, Coubes P, Rousset MC, Brana C, Rougier A, Rondouin G, Bockaert J, Baldy-Moulinier M, Lerner-Natoli M (2002) Inflammatory reactions in human medial temporal lobe epilepsy with hippocampal sclerosis. Brain Research 952:159-169.

Crowder RJ, Freeman RS (1998) Phosphatidylinositol 3-kinase and Akt protein kinase are necessary and sufficient for the survival of nerve growth factor-dependent sympathetic neurons. Journal of Neuroscience 18:29332943.

Crowley LC, Marfell BJ, Waterhouse NJ (2016) Detection of DNA Fragmentation in Apoptotic Cells by TUNEL. Cold Spring Harb Protoc 2016.

Datta SR, Dudek H, Xu T, Masters S, Haian F, Gotoh Y, Greenberg ME (1997) Akt phosphorylation of BAD couples survival signals to the cell- intrinsic death machinery. Cell 91:231-241.

Dingledine R, Varvel NH, Dudek FE (2014) When and how do seizures kill neurons, and is cell death relevant to epileptogenesis? Advances in Experimental Medicina and Biology 813.

Elliott JO, Lu B, Shneker B, Charyton C, Layne Moore J (2009) Comorbidity, health screening, and quality of life among persons with a history of epilepsy. Epilepsy and Behavior 14:125-129.

Engel T, Henshall DC (2009) Apoptosis, Bcl-2 family proteins and caspases: The ABCs of seizure-damage and epileptogenesis? International Journal of Physiology, Pathophysiology and Pharmacology 1:97-115.

Ferrelli $F$ et al. (2015) Serum glucocorticoid inducible kinase (SGK)-1 protects endothelial cells against oxidative stress and apoptosis induced by hyperglycaemia. Acta Diabetologica 52:55-64.

Fujikawa D (2006) Neuroprotective strategies in status epilepticus. In: Status epilepticus: Mechanisms and management. (Wasterlain CT, DM, ed), pp 463-480: Cambridge: MIT Press.

Goldberg EM, Coulter DA (2013) Mechanisms of epileptogenesis: A convergence on neural circuit dysfunction. Nature Reviews Neuroscience 14:337-349.

Henshall DC, Araki T, Schindler CK, Lan JQ, Tiekoter KL, Taki W, Simon RP (2002) Activation of Bcl-2-associated death protein and counterresponse of Akt within cell populations during seizure-induced neuronal death. Journal of Neuroscience 22:8458-8465.

Hopkins KJ, Wang GJ, Schmued LC (2000) Temporal progression of kainic acid induced neuronal and myelin degeneration in the rat forebrain. Brain Research 864:69-80.

Jessberger S, Parent JM (2015) Epilepsy and adult neurogenesis. Cold Spring Harbor Perspectives in Biology 7. Jonas EA, Porter GA, Alavian KN (2014) Bcl-xL in neuroprotection and plasticity. Frontiers in Physiology 5:1-11.

Kanner AM, Trimble M, Schmitz B (2010) Postictal affective episodes. Epilepsy and Behavior 19:156-158.

Kasugai M, Akaike K, Imamura Si, Matsukubo H, Tojo H, Nakamura M, Tanaka S, Sano A (2007) Differences in two mice strains on kainic acid-induced amygdalar seizures. Biochemical and Biophysical Research Communications 357:1078-1083.

Kim YS, Choi MY, Lee DH, Jeon BT, Roh GS, Kim HJ, Kang SS, Cho GJ, Choi WS (2014) Decreased interaction between FoxO3a and Akt correlates with seizure-induced neuronal death. Epilepsy Research 108:367378.

Kobau R, Gilliam F, Thurman DJ (2006) Prevalence of self-reported epilepsy or seizure disorder and its associations with self-reported depression and anxiety: Results from the 2004 Healthstyles Survey. Epilepsia 47:1915-1921.

Kobayashi T, Deak M, Morrice N, Cohen P (1999) Characterization of the structure and regulation of two novel isoforms of serum- and glucocorticoid-induced protein kinase. The Biochemical journal 344 Pt 1:189-197. 
Krajewska M, Mai JK, Zapata JM, Ashwell KWS, Schendel SL, Reed JC, Krajewski S (2002) Dynamics of expression of apoptosis-regulatory proteins Bid, Bcl-2, Bcl-X, Bax and Bak during development of murine nervous system. Cell death and differentiation 9:145-157.

Kuhn HD-A, H; Gage, FH. (1996) Neurogenesis in the dentate gyrus of the adult rat: age-related decrease of neuronal progenitor proliferation. Journal of Neuroscience 16:2027-2033.

Levesque M, Avoli M, Bernard C (2016) Animal models of temporal lobe epilepsy following systemic chemoconvulsant administration. J Neurosci Methods 260:45-52.

Löscher W (2002) Animal models of epilepsy for the development of antiepileptogenic and disease-modifying drugs. A comparison of the pharmacology of kindling and post-status epilepticus models of temporal lobe epilepsy. Epilepsy Research 50:105-123.

Löscher W (2012) Strategies for antiepileptogenesis: Antiepileptic drugs versus novel approaches in post-status epilepticus models of temporal love epilepsy. Jasper's Basic Mechanisms of the Epilepsies.

Löscher W, Schmidt D (2011) Modern antiepileptic drug development has failed to deliver: Ways out of the current dilemma. Epilepsia 52:657-678.

Mathern GW, Babb TL, Armstrong DL (1997) Hippocampal sclerosis. Epilepsy: a comprehensive textbook:133155.

Mathern GW, Adelson PD, Cahan LD, Leite JP (2002) Hippocampal neuron damage in human epilepsy: Meyer's hypothesis revisited. Prog Brain Res 135:237-251.

McCaig CA, P; Shtaya, A; Omar, AS; Green, AR; Kind, CN; Pereira, AC; Naray-Fejes-Toth, A; Fejes-Toth, G; YáñezMuñoz, RJ; Murray, JT; Jainsworth, AH. (2019) Induction of cell survival kinase Sgk1: A possible novel mechanism for a-phenyl-N-tert-butylnitrone in experimental stroke. Journal of Cerebral Blood Flow \& Metabolism 39:1111-1121.

McKhann GM, 2nd, Wenzel HJ, Robbins CA, Sosunov AA, Schwartzkroin PA (2003) Mouse strain differences in kainic acid sensitivity, seizure behavior, mortality, and hippocampal pathology. Neuroscience 122:551561.

Miranda P, Cadaveira-Mosquera A, Gonzalez-Montelongo R, Villarroel A, Gonzalez-Hernandez T, Lamas JA, Alvarez de la Rosa D, Giraldez T (2013) The neuronal serum- and glucocorticoid-regulated kinase 1.1 reduces neuronal excitability and protects against seizures through upregulation of the M-current. The Journal of neuroscience : the official journal of the Society for Neuroscience 33:2684-2696.

Motoyama N, Wang F, Roth KA, Sawa H, Nakayama KI, Nakayama K, Negishi I, Senju S, Zhang Q, Fujii S, Loh DY (1995) Massive cell death of immature hematopoietic cells and neurons in Bcl-x-deficient mice. Science 267:1506-1510.

Murphy BM, Engel T, Paucard A, Hatazaki S, Mouri G, Tanaka K, Tuffy LP, Jimenez-Mateos EM, Woods I, Dunleavy M, Bonner HP, Meller R, Simon RP, Strasser A, Prehn JHM, Henshall DC (2010) Contrasting patterns of Bim induction and neuroprotection in Bim-deficient mice between hippocampus and neocortex after status epilepticus. Cell death and differentiation 17:459-468.

O'Connor L, Strasser A, O'Reilly LA, Hausmann G, Adams JM, Cory S, Huang DCS (1998) Bim: A novel member of the Bcl-2 family that promotes apoptosis. EMBO Journal 17:384-395.

Parent JM, Elliott RC, Pleasure SJ, Barbaro NM, Lowenstein DH (2006) Aberrant seizure-induced neurogenesis in experimental temporal lobe epilepsy. Annals of neurology 59:81-91.

Park JH, Kim CK, Lee SB, Lee KH, Cho SW, Ahn JY (2016) Akt attenuates apoptotic death through phosphorylation of $\mathrm{H} 2 \mathrm{~A}$ under hydrogen peroxide-induced oxidative stress in PC12 cells and hippocampal neurons. Scientific reports 6:21857. 
Pérez-Domper P, Palomo V, Gradari S, Gil C, de Ceballos ML, Martínez A, Trejo JL (2017) The GSK-3-inhibitor VP2.51 produces antidepressant effects associated with adult hippocampal neurogenesis. Neuropharmacology 116:174-187.

Pitkanen A, Lukasiuk K (2009) Molecular and cellular basis of epileptogenesis in symptomatic epilepsy. Epilepsy Behav 14 Suppl 1:16-25.

Pitkänen A (2002) Efficacy of current antiepileptics to prevent neurodegeneration in epilepsy models. Epilepsy Research 50:141-160.

Pitkänen A, Kubova H (2004) Antiepileptic drugs in neuroprotection. Expert Opinion on Pharmacotherapy 5:777798.

Putcha GV, Moulder KL, Golden JP, Bouillet P, Adams JA, Strasser A, Johnson EM (2001) Induction of BIM, a proapoptotic BH3-only BCL-2 family member, is critical for neuronal apoptosis. Neuron 29:615-628.

Ravizza T, Gagliardi B, Noé F, Boer K, Aronica E, Vezzani A (2008) Innate and adaptive immunity during epileptogenesis and spontaneous seizures: Evidence from experimental models and human temporal lobe epilepsy. Neurobiology of Disease 29:142-160.

Riazi K, Galic MA, Pittman QJ (2010) Contributions of peripheral inflammation to seizure susceptibility: Cytokines and brain excitability. Epilepsy Research 89:34-42.

Ribak CE, Tran PH, Spigelman I, Okazaki MM, Nadler JV (2000) Status epilepticus-induced hilar basal dendrites on rodent granule cells contribute to recurrent excitatory circuitry. The Journal of comparative neurology 428:240-253.

Roth KA, Kuan CY, Haydar TF, D'Sa-Eipper C, Shindler KS, Zheng TS, Kuida K, Flavell RA, Rakic P (2000) Epistatic and independent functions of Caspase-3 and $\mathrm{Bcl}-\mathrm{XL}$ in developmental programmed cell death. Proceedings of the National Academy of Sciences of the United States of America 97:466-471.

Roy M, Hom JJ, Sapolsky RM (2002) HSV-mediated delivery of virally derived anti-apoptotic genes protects the rat hippocampus from damage following excitotoxicity, but not metabolic discruption. Gene Therapy 9:214-219.

Royle SJ, Collins FC, Rupniak HT, Barnes JC, Anderson R (1999) Behavioural analysis and susceptibility to CNS injury of four inbred strains of mice. Brain Res 816:337-349.

Schauwecker PE, Steward O (1997) Genetic determinants of susceptibility to excitotoxic cell death: implications for gene targeting approaches. Proceedings of the National Academy of Sciences of the United States of America 94:4103-4108.

Schindelin J, Arganda-Carreras I, Frise E, Kaynig V, Longair M, Pietzsch T, Preibisch S, Rueden C, Saalfeld S, Schmid B, Tinevez JY, White DJ, Hartenstein V, Eliceiri K, Tomancak P, Cardona A (2012) Fiji: an opensource platform for biological-image analysis. Nat Methods 9:676-682.

Schmued LC, Albertson C, Slikker W (1997) Fluoro-Jade: A novel fluorochrome for the sensitive and reliable histochemical localization of neuronal degeneration. Brain Research 751:37-46.

Sofroniew MV (2014) Astrogliosis. Cold Spring Harbor Perspectives in Biology 7.

Tellez-Zenteno JF, Patten SB, Jetté N, Williams J, Wiebe S (2007) Psychiatric comorbidity in epilepsy: A populationbased analysis. Epilepsia 48:2336-2344.

Van Gassen KLI, De Wit M, Koerkamp MJAG, Rensen MGA, Van Rijen PC, Holstege FCP, Lindhout D, De Graan PNE (2008) Possible role of the innate immunity in temporal lobe epilepsy. Epilepsia 49:1055-1065.

Vezzani A, French J, Bartfai T, Baram TZ (2011) The role of inflammation in epilepsy. Nature Reviews Neurology 7:31-40.

Vezzani AB, TZ (2007) New roles for interleukin-1 Beta in the mechanisms of epilepsy. Epilepsy Currents 7:45-50. 
Vismer MS, Forcelli PA, Skopin MD, Gale K, Koubeissi MZ (2015) The piriform, perirhinal, and entorhinal cortex in seizure generation. Frontiers in Neural Circuits 9:1-14.

Wang DH, Z; Li, L; Yuan, Y; Xiang, L; Ni, C; Yu, W. (2019) Intracarotid cold saline infusion contributes to neuroprotection in MCAO-induced ischemic stroke in rats via serum and glucocorticoid-regulated kinase 1. Molecular Medicine Reports 20:3942-3950.

Wang Q, Yu S, Simonyi A, Sun GY, Sun AY (2005) Kainic acid-mediated excitotoxicity as a model for neurodegeneration. Molecular Neurobiology 31:3-16.

Wesch D, Miranda P, Afonso-Oramas D, Althaus M, Castro-Hernandez J, Dominguez J, Morty RE, Clauss W, Gonzalez-Hernandez T, Alvarez de la Rosa D, Giraldez T (2010) The neuronal-specific SGK1.1 kinase regulates \{delta\}-epithelial $\mathrm{Na}+$ channel independently of PY motifs and couples it to phospholipase $\mathrm{C}$ signaling. American journal of physiology Cell physiology 299:C779-790.

Yan BC, Xu P, Gao M, Wang J, Jiang D, Zhu X, Won MH, Su PQ (2018) Changes in the Blood-Brain Barrier Function Are Associated With Hippocampal Neuron Death in a Kainic Acid Mouse Model of Epilepsy. Front Neurol 9:775

Youle RJ, Strasser A (2008) The BCL-2 protein family: Opposing activities that mediate cell death. Nature Reviews Molecular Cell Biology 9:47-59. 


\section{FIGURE LEGENDS}

Figure 1. Fluoro-Jade $C$ staining reveals significantly decreased neuronal in Tg.sgk1 mice after SE. (A) Cumulative plot representing the percentage of B6.WT (blue) and B6.Tg.sgk1 (green) mice reaching the indicated Racine stages after KA injection. Stage 7 corresponds to death associated to SE. Only mice reaching stage 6 were used to evaluate neuronal death (highlighted in orange) (B6.WT $\mathrm{N}=26$, B6.Tg.sgk1 $\mathrm{N}=24$ ). Part of the data in this graph have been obtained from (Armas-Capote et al., 2019). (B) Representative confocal images of FJC stained brain sections B6.WT (left column) and B6.Tg.sgk1 mice (right column) reaching Racine stage 6. Hippocampus (Hip), auditive cortex $(\mathrm{Au})$ and piriform cortex (Pir) brain areas are shown. Scale bar $=100 \mu \mathrm{m}$. (C) Quantitative analysis of neurodegeneration events (FJC-positive cells) normalized to area $\left(\mathrm{mm}^{2}\right)$ corresponding to regions shown in B from B6.WT and B6.Tg.sgk1 mice brain slices. Data are mean \pm SEM ( $N=5 ; n=25$; Mann-Whitney test, $\left.{ }^{* *} \mathrm{p}<0.01\right)$. (D) Cumulative plot representing the percentage of FVB mice reaching the indicated Racine stages. Only mice reaching stage 6 were used to evaluate neuronal death (highlighted in orange; 72h after KA treatment) (FVB.WT $\mathrm{N}=19$; FVB.Tg.sgk1 N=19). (E) Representative confocal images corresponding to FJC staining of brain slices from same regions as B, from FVB.WT (left column) and FVB.Tg.sgk1 mice (right column) reaching Racine stage 6. Scale bar $=100 \mu \mathrm{m}$. (F) Quantification of FJC positive cells normalized to area $\left(\mathrm{mm}^{2}\right)$ in both genotypes on the FVB genetic background. Data are mean \pm SEM $\left(N=7 ; n=35\right.$; Mann-Whitney test, $\left.{ }^{\star} p<0.05,{ }^{\star *} p<0.01\right)$

Figure 2. SGK1.1 has a dual role as an anticonvulsant and as a neuroprotective factor in SE. (A) Cumulative plot representing the percentage of EMD638683-pretreated B6.WT and B6.Tg.sgk1 mice reaching the indicated Racine stages after KA injection. Mice reaching stage 6 were used to evaluate neuronal death (highlighted in orange). Data from EMD638683-untreated animals (Figure 1A) are shown in grey for reference. (B6.WT N=26, B6.Tg.sgk1 N=21). (B) Representative confocal images corresponding to FJC staining of brain sections from B6.WT (left column) and B6.Tg.sgk1 mice (right column) pretreated with EMD638683. Brain regions shown are hippocampus (Hip), auditive cortex (Au) and piriform cortex (Pir). Scale bar = $100 \mu \mathrm{m}$. (C) Quantitative analysis of FJC-positive cells in EMD638683-pretreated B6.WT $(N=8 ; n=40)$ and B6.Tg.sgk1 $(N=5 ; n=25)$ mice in the areas shown in B. Data are mean \pm SEM (Mann-Whitney test; ns, not significant). (D) Cumulative plot representing the percentage of XE991-pretreated B6.WT and B6.Tg.sgk1 mice reaching the indicated Racine stages after KA injection (B6.WT N=26, B6.Tg.sgk1 N=24). Mice reaching stage 6 were used to evaluate neuronal death (highlighted in orange). Data from XE991-untreated animals (Figure 1A) are shown in grey for reference. Part of the data in this graph have been obtained from (Armas-Capote et al., 2019). (E) Representative images of FJC stained brain sections from animals in A corresponding to hippocampus (Hip), auditive cortex (Au) and piriform 
cortex (Pir). Scale bar $=100 \mu \mathrm{m}$. (F) Quantitative analysis of FJC-positive cells on brain slices from B6.WT and B6.Tg.sgk1 mice in the areas shown in E. Data are mean \pm SEM $\left(N=7, n=35\right.$; Mann-Whitney test; ${ }^{\star} p>0.05$; ns, not significant).

Figure 3. Astrogliosis is decreased in hippocampus and cortex of KA-injected Tg.sgk1 mice. (A) Representative confocal images showing GFAP immunostaining (red, Alexa 494) and DAPI-stained nuclei (blue) for B6.WT and B6.Tg.sgk1, 72h after KA injection in hippocampus (regions DG, CA1 and CA3) and piriform cortex (Pir). Scale bar $=50 \mu \mathrm{m}$. (B) Average GFAP levels in transgenic mice compared to WT. Data are mean \pm SEM, normalized to WT levels ( $N=5$; multiple t-test; * $p<0,05$; ns, not significant). (C) Representative images showing GFAP-positive astrocytes in FVB.WT and FVB.Tg.sgk1 mice, 72h after KA injection in same regions as A. (D) Average GFAP levels in transgenic mice compared to WT. Data are mean \pm SEM normalized to WT levels ( $\mathrm{N}=6$; multiple t-test; ${ }^{*} \mathrm{p}<0,05 ;{ }^{* *} \mathrm{p}<0,01 ; n s$, not significant).

Figure 4. Microgliosis levels are reduced in Tg.sgk1 vs. WT mice after KA treatment. (A) Representative confocal images showing Iba-1 reactivity (green, Alexa 488) and DAPI-stained nuclei (blue) in brain slices from B6.WT and B6.Tg.sgk1 mice after KA injection in hippocampus regions (DG, CA1 and CA3) and piriform cortex (Pir). Scale bar $=50 \mu \mathrm{m}$. (B) Average Iba-1 levels in transgenic mice compared to WT. Data are mean \pm SEM normalized to WT (N=5; multiple t-test; ${ }^{*} \mathrm{p}<0,05$; ns, not significant). (C) Representative confocal images showing lba-1 staining in FVB.WT and FVB.Tg.sgk1 brain slices after KA injection in same areas as A. (D) Average lba-1 levels in transgenic mice compared to WT. Data are mean \pm SEM normalized to WT ( $N=5$; multiple t-test; ${ }^{\star} \mathrm{p}<0,05$; ns, not significant).

Figure 5. SGK1.1 is selectively expressed at the soma and processes of pyramidal neurons. (A) Representative confocal images of HEK293T cells transfected with an empty vector (peCFP-N1) or a vector expressing SGK1.1CFP and stained with anti-SGK1.1 rabbit polyclonal antibody. Scale bar $=10 \mu \mathrm{m}$. (B) Representative confocal images of WT brain slices showing SGK1.1 (green, Alexa 488) and CaMKII (red, Alexa 594) immunostaining of hippocampus CA1 (Hip_CA1) and visual cortex (CTX) areas. Scale bar $=100 \mu \mathrm{m}$. (C) Magnification of whiteframed regions in B. (D) Representative confocal images showing SGK1.1 (green) and PV (red) immunostaining of hippocampus CA1 (Hip_CA1) and visual cortex (CTX) from WT brain slices. (E) Representative confocal images showing SGK1.1 (green, Alexa 488) and GFAP (red, Alexa 594) expression of hippocampus CA3 (Hip_CA3) and visual cortex (CTX). (F) Magnification of white-boxed areas in $\mathrm{E}$. 
Figure 6. SGK1.1 activation exerts anti-apoptotic effects via modulation of apoptosis mediators after KA-induced SE. (A) Representative confocal images of fluorescein-stained cells transfected with the indicated constructs. Arrows point to TUNEL-positive cells. Scale bar $=10 \mu \mathrm{m}$. (B) Quantitative analysis of TUNEL-positive cells after transfection with the indicated constructs and $\mathrm{H}_{2} \mathrm{O}_{2}$ treatment. Bars show mean \pm SEM ( $n=5$; cells were counted on at least 6 different fields per condition; one-way ANOVA followed by multiple comparison test; ${ }^{*} \mathrm{p}<0.05$; ns, not significant). (C) Top, Representative western blot of Bim protein abundance in the hippocampus of WT and transgenic mice 24h after KA administration. Bottom, total protein loading. (D) Top, Representative western blot of $\mathrm{BCl}-\mathrm{X}_{\mathrm{L}}$ protein abundance in the hippocampus of WT and transgenic mice $24 \mathrm{~h}$ after KA administration. Bottom, total protein loading. (E) Quantification of western blot data. Bars represent mean \pm SEM from WT $(n=4)$ and Tg.sgk1 ( $n=6$; Unpaired t-test; ${ }^{*} p<0.05$ ). Total protein fluorescence staining (stain-free ${ }^{\mathrm{TM}}$, BioRad) was used as loading control.

Figure 7. Activation of SGK1.1 does not alter neurogenesis in hippocampus. (A) Representative confocal images showing merged immunostaining signals corresponding to BrdU (green) and DCX (red) from B6.WT $\left(A_{1}\right)$ and B6.Tg.sgk1 $\left(A_{2}\right)$ in hippocampus DG. Scale bar $=100 \mu \mathrm{m}$. (B) Top, schematic representation showing brain areas for neurogenesis quantification. Bottom, quantification of $\mathrm{BrdU}^{+}$and $\mathrm{DCX}+$ cells per brain section in granular cells of DG (newborn cells, above) and hilus (ectopic neurogenesis, below). Bars represent mean $\pm \mathrm{SEM}(\mathrm{N}=4$; unpaired t-test; ns, not significant) (C) Magnification of white-boxed area in A1. BrdU+ cells (green), DXC+ cells (red) and merged image. 
FIGURE_1

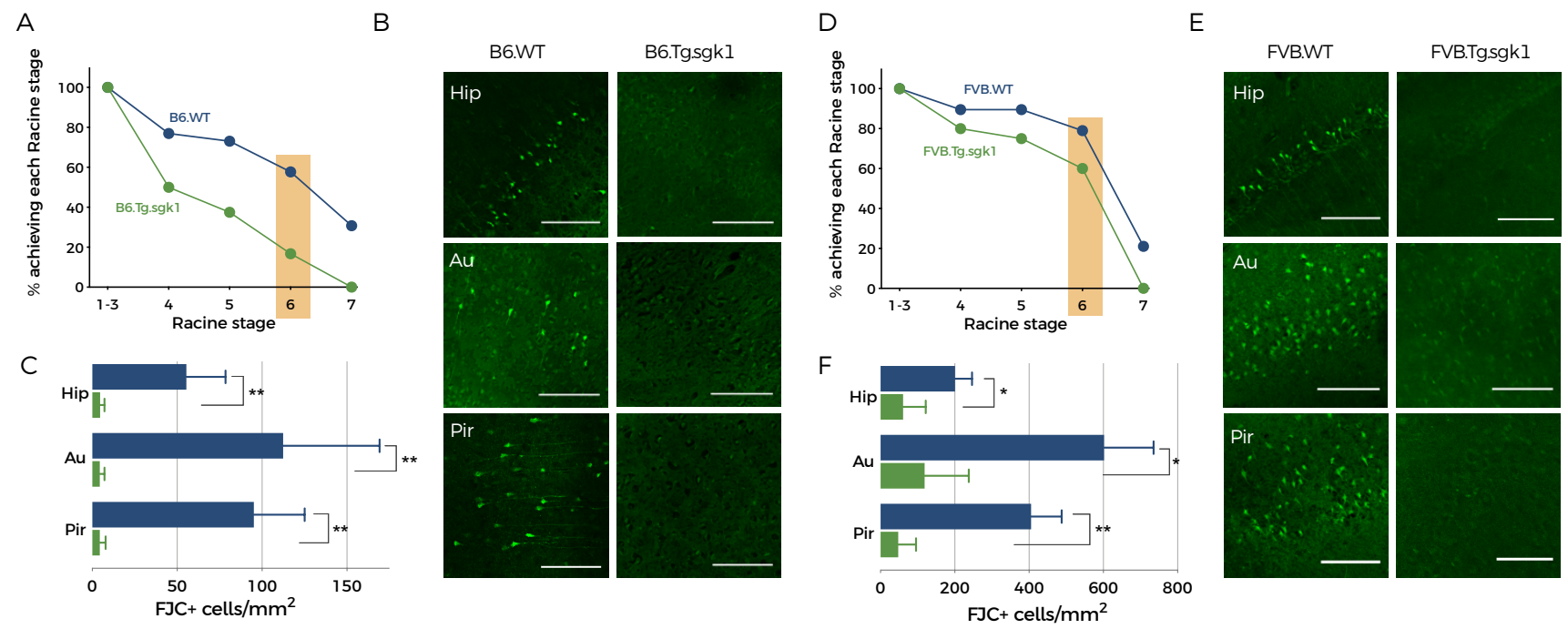


FIGURE_2

A

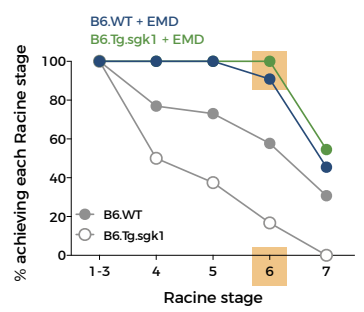

c

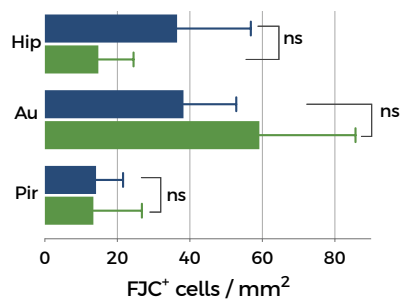

B
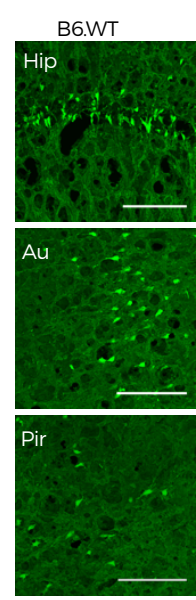

D

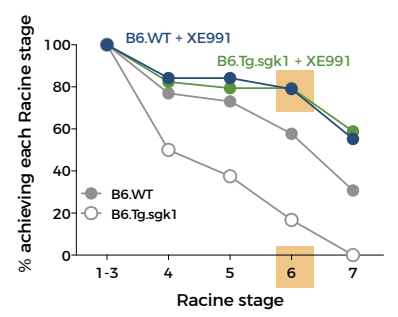

F

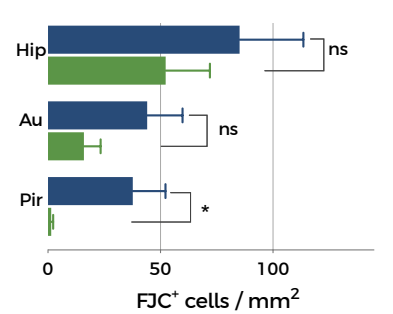

KA + XE991
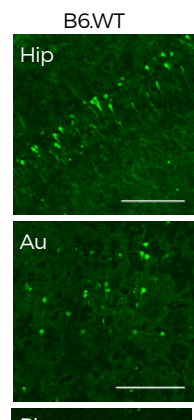

Pir:

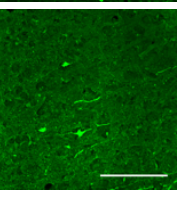

B6.Tg.sgk1

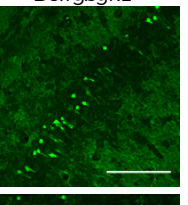

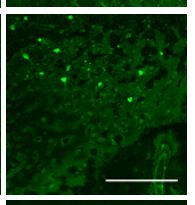

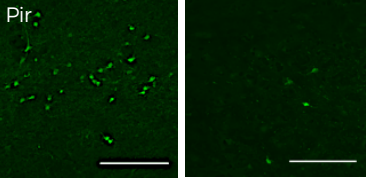


FIGURE_3

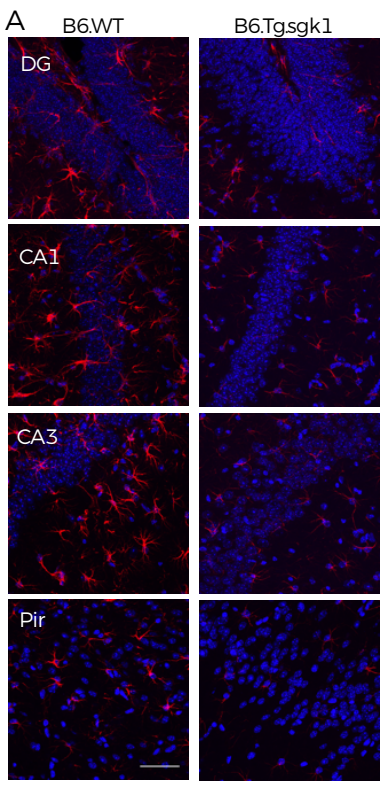

B

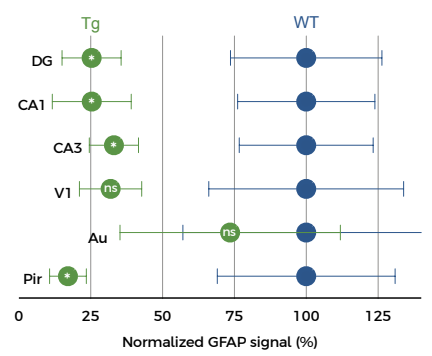

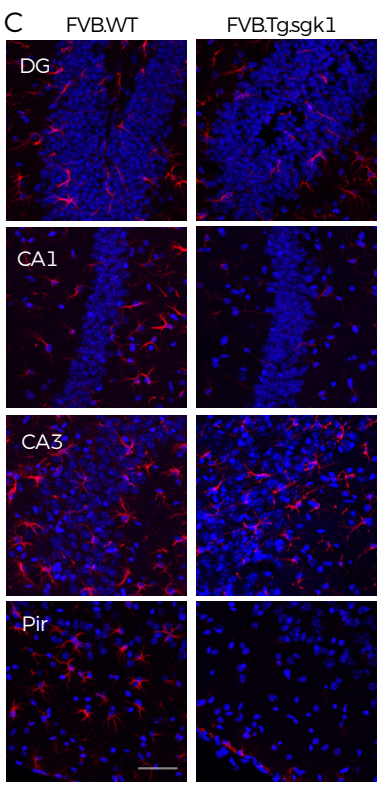

D

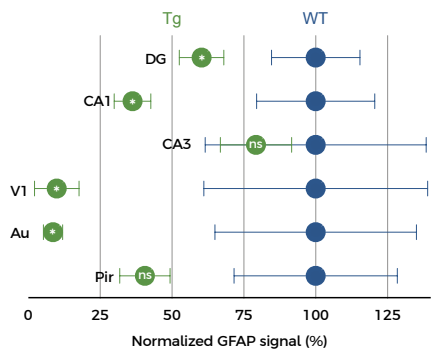


FIGURE_4
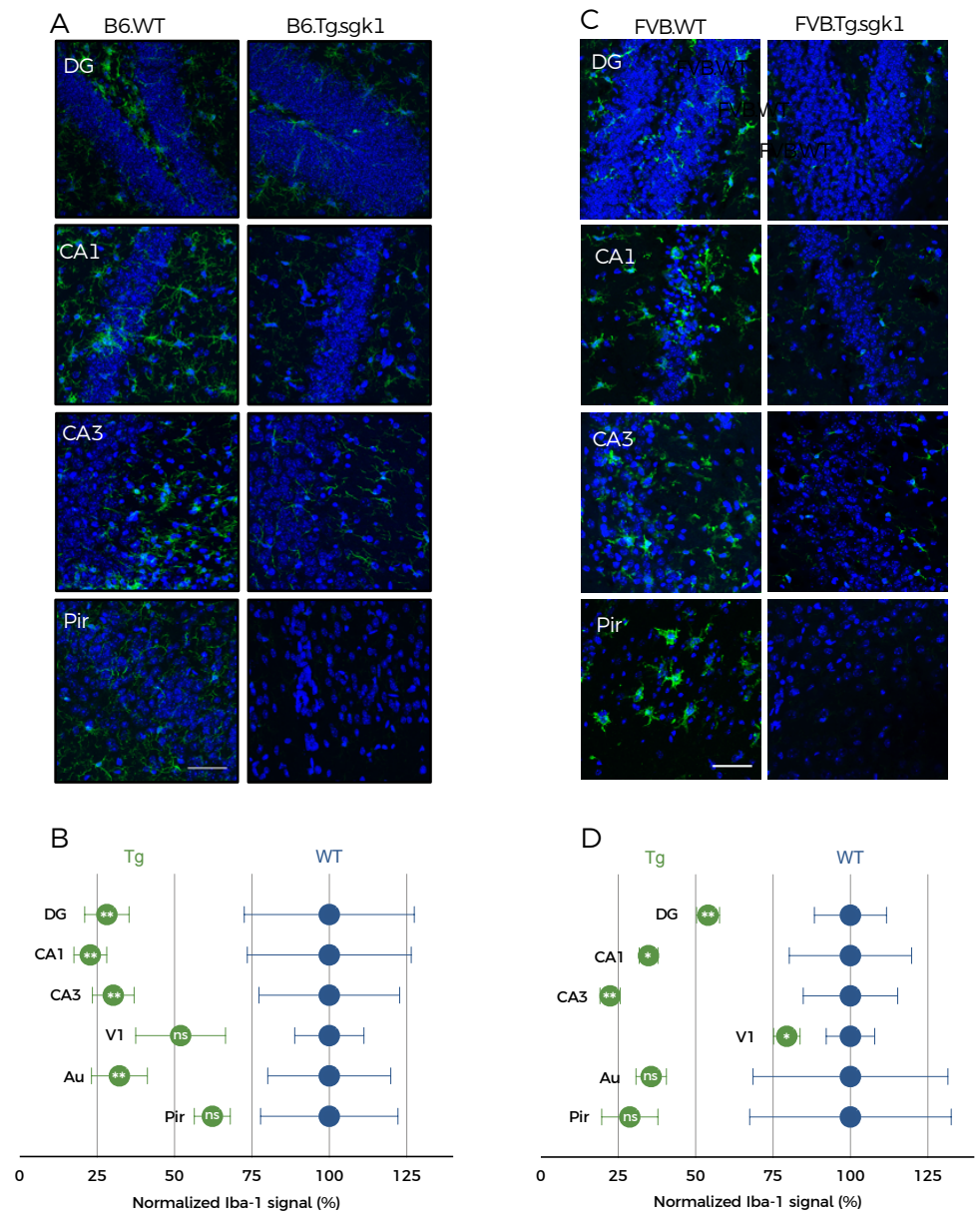
FIGURE_5
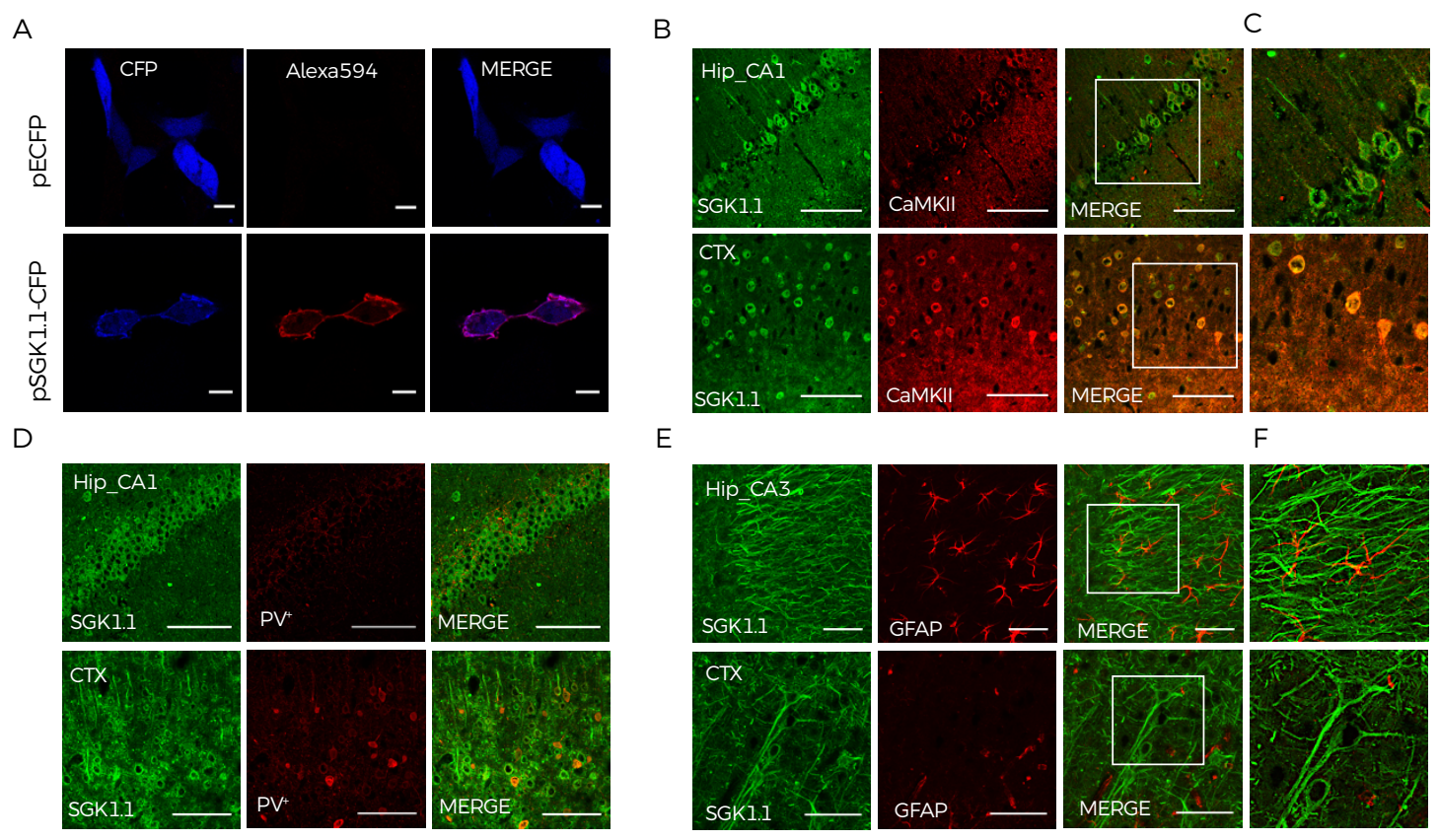
FIGURE_6
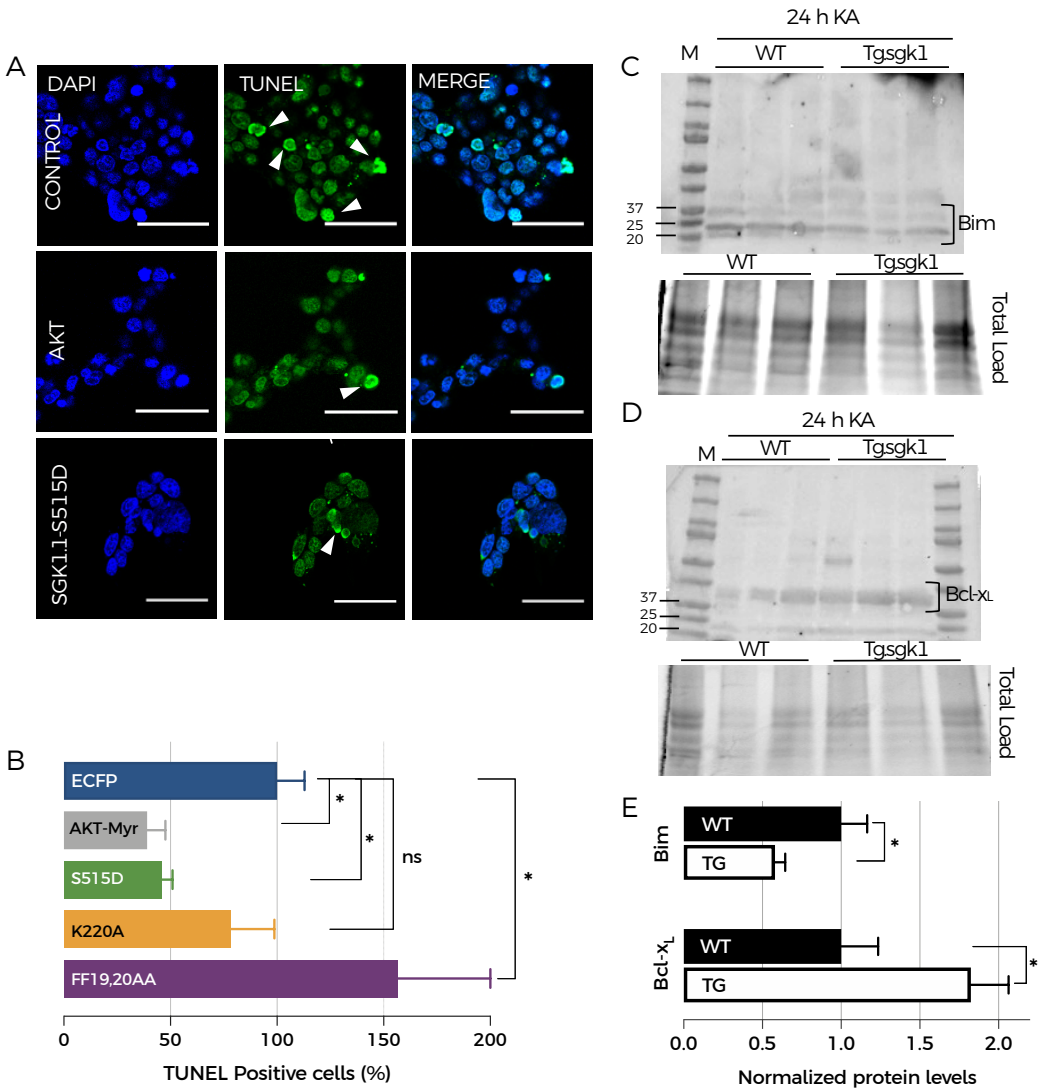


\section{FIGURE_7}
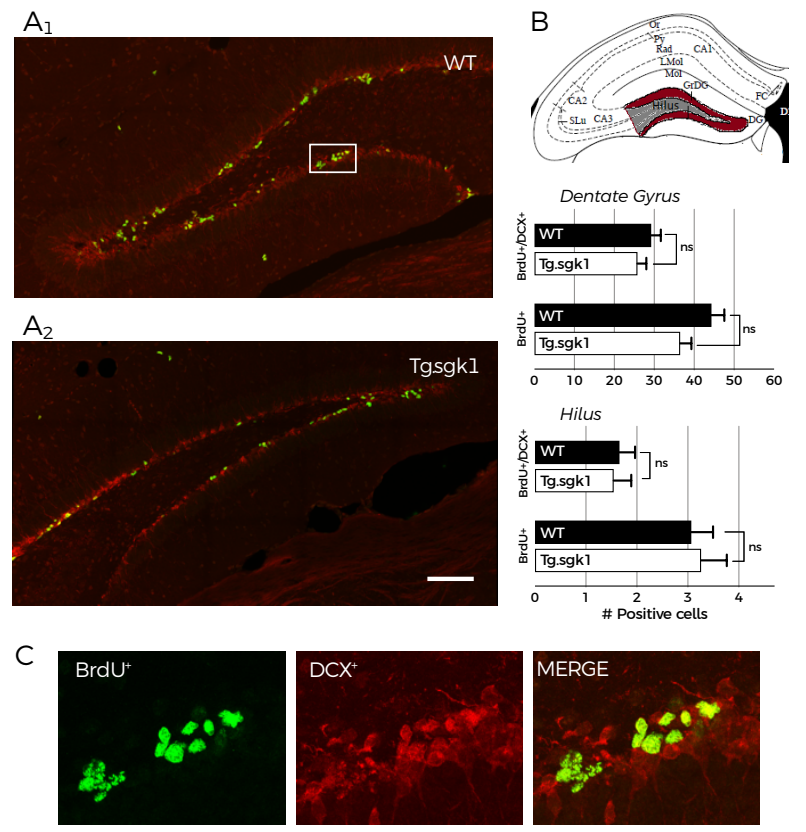